\title{
Two New Beamlines at NSLS-II for Micro-focus, Serial, and Highly Automated Macromolecular Crystallography
}

\author{
Wuxian Shi, and the NSLS-II Structural Biology Group
}

\section{Brookhaven National Laboratory, Upton, NY 11973, USA, wushi@bnl.gov}

The new macromolecular crystallography (MX) beamlines at the National Synchrotron Light Source II, FMX and AMX, deliver beams of unprecedented brightness, stability and versatility. The Highly Automated MX beamline, AMX, has a flux of $4 \times 10^{12} \mathrm{ph} / \mathrm{s}$ in a fixed beam size of $5 \times 5 \mu \mathrm{m}^{2}$, and focuses on fast sample delivery and automated data collection to support projects which require screening of a large number of specimens. The Frontier Micro-focus MX beamline, FMX, delivers a flux of $3.5 \times 10^{12} \mathrm{ph} / \mathrm{s}$ into a flexible beam spot size of $1-10 \mu \mathrm{m}$. The beamline covers a wide energy range from $5-30 \mathrm{keV}$, with potential for high-energy X-ray operation. The experimental stations, beamline automation, and data processing environment are optimized to harness these beam properties to address difficult crystallographic problems [1]. We will present new scientific results from the beamlines to showcase the beamline capabilities. The raster scan with a micron-sized beam on large mosaic crystals is effective in finding a slim volume with single diffractions to obtain a high quality dataset. This practice was instrumental in determining structure of a bacterial RNA riboswitch [2]. Flexible beam size adjustment matching the crystal size allowed successful S-SAD phasing from needle crystals of a G-protein chaperon [3]. Membrane protein crystals in size of 1-5 $\mu \mathrm{m}$ embedded in lipidic cubic phase can be located through fast raster scans and multi-crystal data collection strategies are employed subsequently to obtain a complete dataset [4]. Two serial crystallography approaches using fast raster scans and a high viscosity extrusion injector are established at FMX $[5,6]$. The diffraction images are recorded with up to the maximum detector frame rate of $750 \mathrm{~Hz}$, producing a complete dataset in minutes.

\section{$\underline{\text { References }}$}

1. Fuchs MR, et al., AIP Conf. Proc. 2016; 1741, 030006

2. Peselis A, Serganov A. Nat Chem Biol. 2018; 14(9):887-894.

3. Mou TC, et al., Structure 2019; in press

4. Guo G, Fuchs MR, Shi W, Skinner J, Berman E, Ogata CM, Hendrickson WA, McSweeney S, Liu Q. IUCrJ 2018; 5:238-246.

5. Gao Y, Xu W, Shi W, Soares A, Jakoncic J, Myers S, Martins B, Skinner J, Liu Q, Bernstein H, McSweeney S, Nazaretski E, Fuchs MR. J Synchrotron Radiat. 2018; 25(Pt 5):1362-1370.

6. Miller MS, Maheshwari S, Shi W, Gao Y, Chu N, Soares AS, Cole PA, Amzel LM, Fuchs MR, Jakoncic J, Gabelli SB. Molecules 2019; 24(3): pii: E496. 